\title{
Numerical Investigations of Convective Initiation in Barbados
}

\author{
Kim Whitehall, ${ }^{1}$ Sen Chiao, ${ }^{2}$ and Margarette Mayers-Als ${ }^{3}$ \\ ${ }^{1}$ Atmospheric Physics Program, Howard University, Washington, DC 20059, USA \\ ${ }^{2}$ Meteorology and Climate Science, San José State University, San Jose, CA 95192-0104, USA \\ ${ }^{3}$ Caribbean Institute for Meteorology and Hydrology, Husbands, St. James, BB 23006, Barbados \\ Correspondence should be addressed to Sen Chiao; sen.chiao@sjsu.edu
}

Received 11 March 2013; Accepted 29 May 2013

Academic Editor: Lian Xie

Copyright (C) $2013 \mathrm{Kim}$ Whitehall et al. This is an open access article distributed under the Creative Commons Attribution License, which permits unrestricted use, distribution, and reproduction in any medium, provided the original work is properly cited.

\begin{abstract}
Localized convection in Barbados accounts for hazardous conditions and a significant percentage of the island's annual rainfall. The feature results in rainfall accumulations exceeding $50 \mathrm{~mm}$ in 3 hours or less, over isolated locations. Weather Research and Forecasting model (WRF) simulations are conducted for a rapid convective initiated and heavy precipitation event of 26 August 2008 over Barbados. The simulation results from the $1 \mathrm{~km}$ grid resolution domain depict that the shallow topography on the island plays a significant role in enhancing convective activity under weak synoptically disturbed conditions. The model results also demonstrate that the driving forces for the development of deep convective clouds include low-level moisture convergence that form as a result of the temperature differential between the land and the ocean and forced low-level uplift as a result of the blocking by the topography. The high-resolution WRF simulations demonstrate its capability to accurately capture the low-level flow over the island, as well as the orientation of the divergence and convergence patterns throughout the depth of the atmosphere. These results are heartening to use the WRF as a resource for studying deep convection in Barbados for disaster managers and water resource managers.
\end{abstract}

\section{Introduction}

The intensity and frequency of rainfall events in the Caribbean significantly impact agriculture, socioeconomic structures, and disaster management. The Eastern Caribbean region receives most of its rainfall from events embedded in synoptic weather features such as the Intertropical Convergence Zone, easterly waves, storms, and hurricanes, during the rainy season from June to November [1]. The rainfall totals on these islands are also impacted by short-lived localized rainfall associated with nonsynoptic boundary-layer convergence zones driven by temperature or moisture gradients such as sea-breeze fronts [2], drylines, and topography-enhanced flows $[3,4]$. One category of such events is nighttime localized rainfall events that gradually contribute to annual rainfall totals. The second category is high-intensity daytime localized rainfall events (deep localized convection) that are especially significant because they accumulate totals in one event comparable to that of a monthly total in the rainy season. These events are short-lived, highly spatially localized and may occur outside of the rainy season [5]. These deep localized convection events have been found to be initiated by daytime surface heating [6] and topographic enhanced flows [7] on large islands where sea-breeze-assisted mesoscale convective complexes are generated, but their existence on small islands-less than $1000 \mathrm{~km}^{2}$, with shallow topography-less than $1 \mathrm{~km}$ elevation, is not well known.

The island of Barbados $\left(59^{\circ} 32 \mathrm{~W}, 13^{\circ} 10 \mathrm{~N}\right)$ is $430 \mathrm{~km}^{2}$ with the highest elevation $336 \mathrm{~m}$ ASL approximately at the center of the island. It is the most easterly Caribbean island located in the trade wind regime. Skeete [5] observed that in Barbados, deep localized convection occurs approximately 30 days annually, up to half of which occur outside of the rainy season. Though Skeete [5] was able to hypothesize the typical conditions that lead to intense localized convection in Barbados using observations, the criteria are rather subjective and often fail. Garstang et al. [8] considered the wind field from pilot balloon measurements above Barbados in their study of heat islands and concluded downward motion occurs over the island during the day and upward motion downwind from it. Mahrer and Pielke [9] explained through numerical 


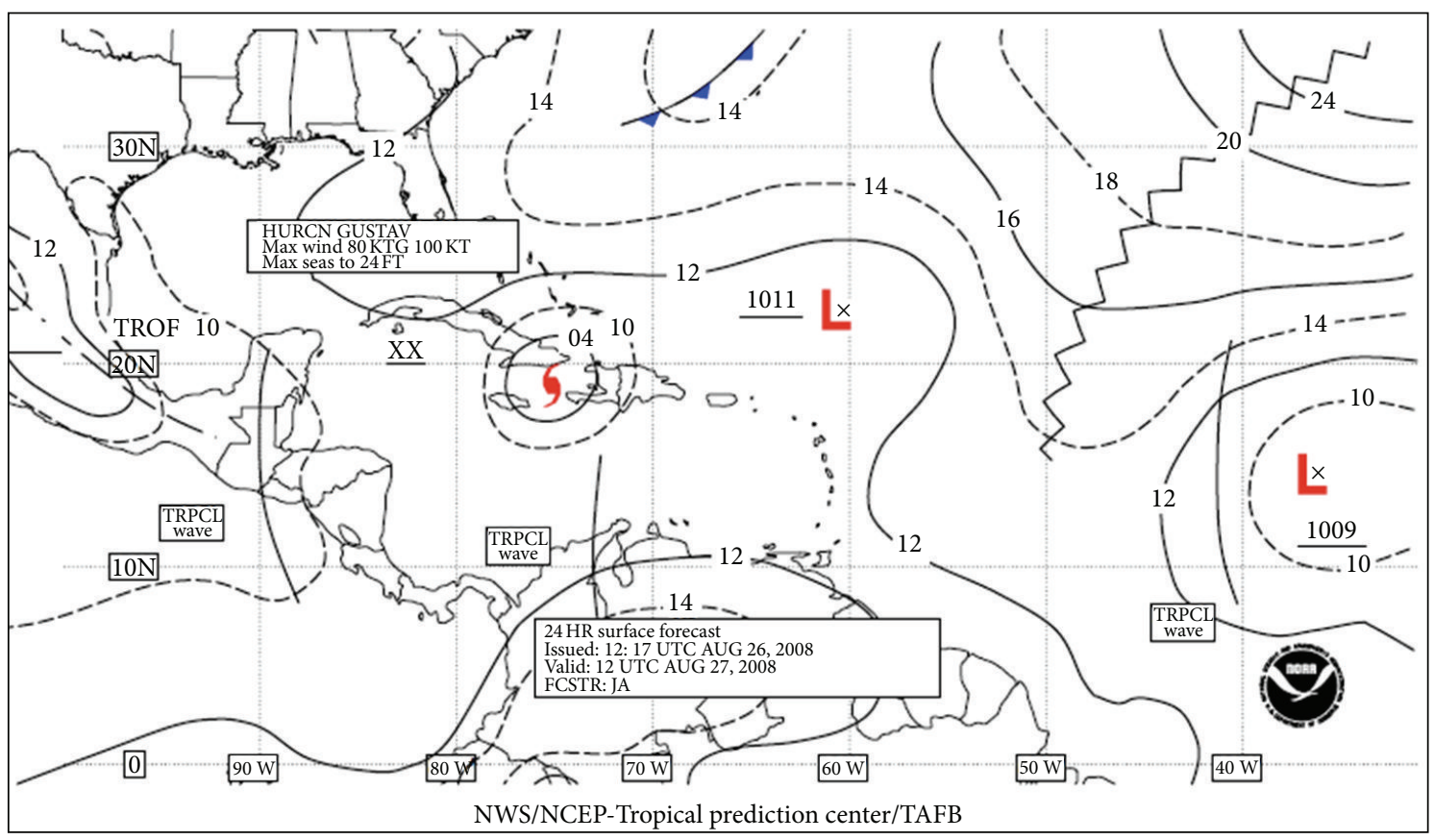

FIgURE 1: Surface forecast of the Caribbean region valid at 1200 UTC 27 August 2008.

methods and field experiments that nighttime rainfall events on synoptically undisturbed days $\left(U \geq 12 \mathrm{~ms}^{-1}\right)$ are related to the topography in Barbados. They concluded that the presence of topography modified the low-level flow over the island creating a convergence zone that allowed for shallow convection growth associated mostly with sea-breeze circulations. Savijärvi and Matthews [10] simulated the wind flow over small heat islands in trade wind locations for synoptically stable days. They found that the sea breeze of a small island similar to Barbados increased in calm conditions $\left(U=0 \mathrm{~ms}^{-1}\right)$. But in weak to moderate conditions $\left(3 \mathrm{~ms}^{-1} \leq\right.$ $U \leq 6 \mathrm{~ms}^{-1}$ ), the morning leeside sea breeze cell advected towards the sea and disappeared, while a windward coast cell remained over the island transforming into a heat island type perturbation. Both Mahrer and Pielke [9] and Savijärvi and Matthews [10] determined the time for sea breeze formation occurrence is 1800 UTC (1400 LST).

This study thus seeks to highlight the formation of deep localized convection in Barbados via numerical simulations of such a case that occurred on 26 August, 2008. The scientific question to be addressed is what was the role of the topography in the evolution and structure of the convection that ultimately became severe localized flooding. We hypothesize the topography triggers convective activity under weak synoptically disturbed conditions with zonal low-level flow below $5 \mathrm{~ms}^{-1}\left(U \leq 5 \mathrm{~ms}^{-1}\right)$. Using a high-resolution numerical modeling approach, we hope to contribute to a guideline for improving forecasts of these short-ranged severe hazard weather events.

\section{Data and Methods}

2.1. Mesoscale and Synoptic Environment. The Barbados Meteorological Office (BMS), located to the southeast of the island, reported a flash flooding event in the north of the island on 26 August, 2008, between the hours of 1500 UTC and 1700 UTC that was associated with deep localized convection. The mesoscale and synoptic environment surrounding this event is presented here via observations from the BMS, surface analysis from BMS and NOAA, and satellite imagery from RAMSDIS-CIRA/RAMM. Data from a daily rain-gauge network are used to verify accumulated rainfall totals.

The synoptic environment, represented by the surface analysis for 26 August 20081200 UTC (Figure 1) and satellite imagery (Figure 2) over the Caribbean region, indicated two major features within the Eastern Caribbean location, a trough system to the north of the Caribbean island chain between $23^{\circ} \mathrm{N} 62^{\circ} \mathrm{W}$ and $28^{\circ} \mathrm{N}$ and $66^{\circ} \mathrm{W}$, and a tropical wave associated with a low-pressure center $(\sim 1012 \mathrm{hPa})$ between $19^{\circ} \mathrm{N} 57^{\circ} \mathrm{W}$ and $23^{\circ} \mathrm{N} 59^{\circ} \mathrm{W}$. These two low-pressure systems within the region caused a weak pressure gradient hence the low wind speeds (less than $5 \mathrm{~ms}^{-1}$ ) observed in the mesoscale environment.

The mesoscale environment is represented by data from the BMS and the $1 \mathrm{~km}$ visible satellite imagery. The BMS meteorological observations include standard station measurements of temperature, surface winds, humidity, precipitation, and cloud amounts and types. Unfortunately, there were no radiosonde launches for the period from 5 August 2008 to 28 August 2008 and radar information was not available. The meteorological observations indicated that the morning temperatures increased rapidly from $28.0^{\circ} \mathrm{C}$ at $1200 \mathrm{UTC}$ to $31.0^{\circ} \mathrm{C}$ by 1537 UTC. The measured wind speeds, $U$, during that time were less than $5 \mathrm{~ms}^{-1}$ and the wind direction was predominantly between the south and southeasterly directions (Table 1). The BMS also reported relatively clear skies. 


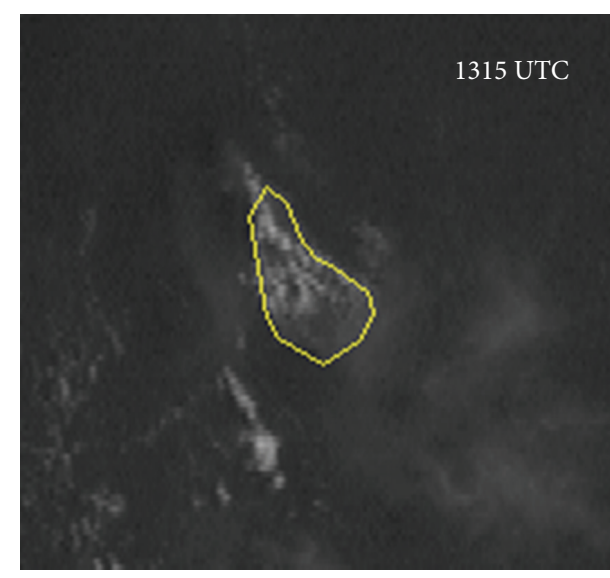

(a)

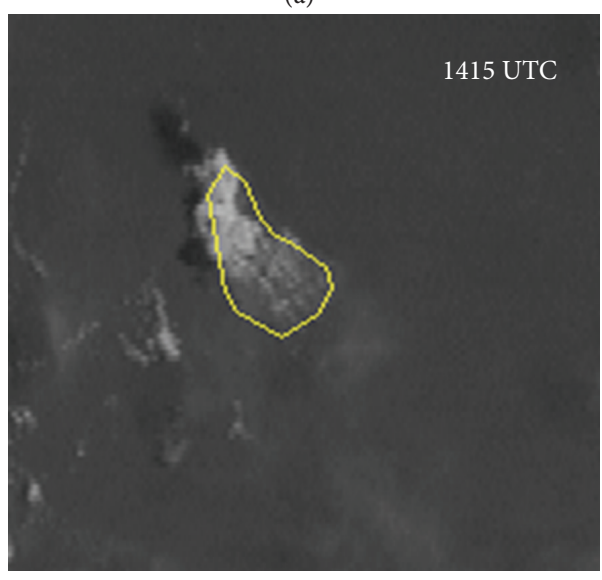

(c)

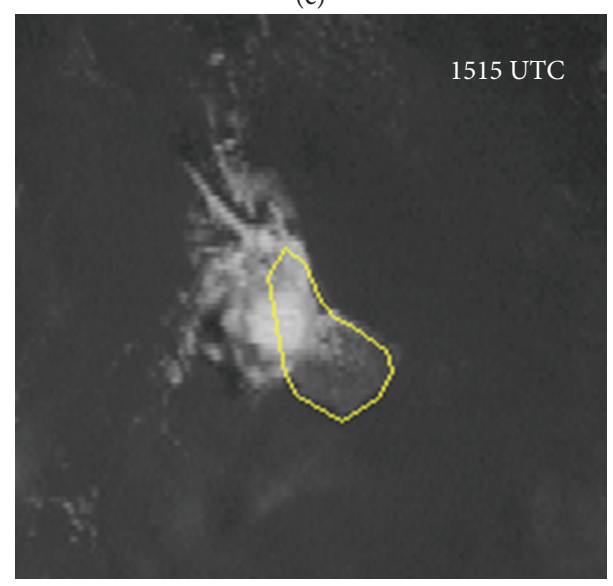

(e)

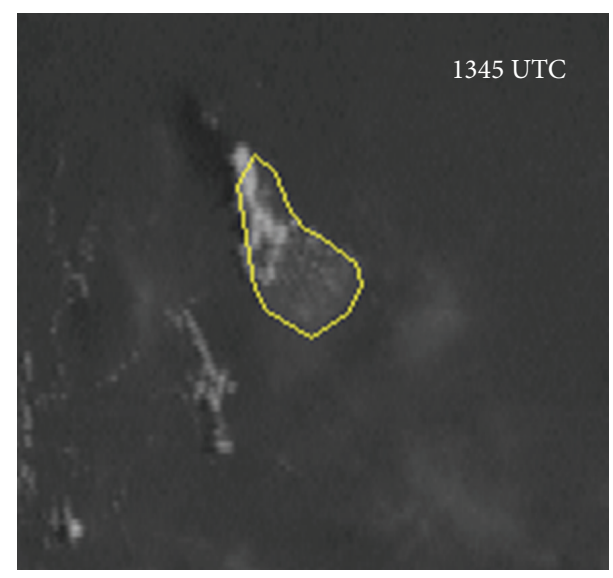

(b)

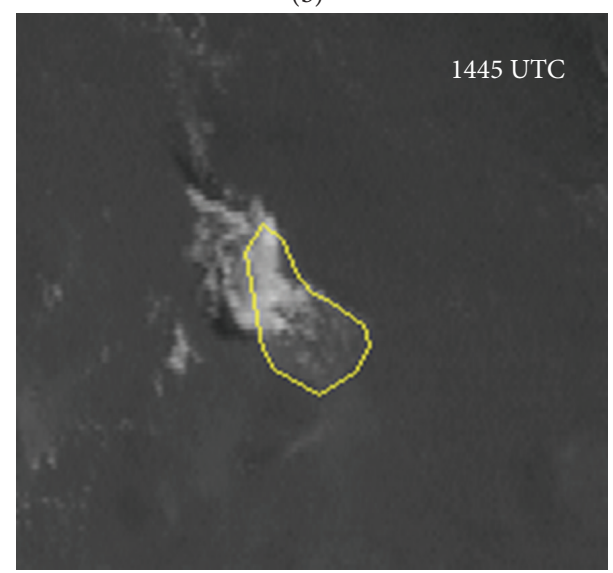

(d)

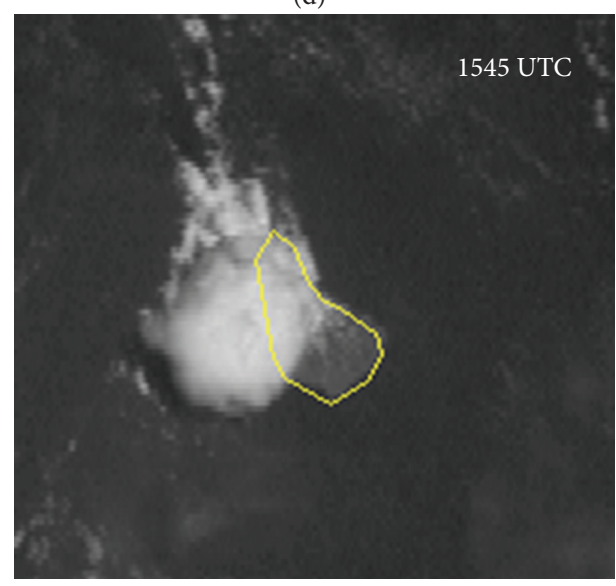

(f)

FIGURE 2: The time series from 1315 UTC to 1545 UTC of visible satellite imagery (RAMSDIS-CIRA/RAMM) at $1 \mathrm{~km}$ resolution centered over Barbados.

The satellite imagery indicates cumulus cloud development over the north of the island commencing around 1315 UTC. The cumulus clouds grew in depth and became organized. By 1545 UTC, there was a cloudy area covering the northern and western portions of the island. The satellite imagery in Figure 2 shows the temporal development of the system, reaching maximum intensity by 1615 UTC over the island. The deep localized convection feature observed between 1415 UTC and 1545 UTC is the focus of this study.
2.2. Numerical Model and Experiment Design. Numerical simulations were performed using the nonhydrostatic WRF$A R W$ version 3.2.1. Detailed information about the WRF model may be found at http://www.wrf-model.org/. A twoway-nested simulation of the WRF-ARW model was configured with grid spacing of $3.0 \mathrm{~km}$ and $1.0 \mathrm{~km}$ for domains 1 and 2 over the Eastern Caribbean area, respectively (Figure 3(a)). A vertical resolution of 90 sigma levels extending from the surface to $10 \mathrm{hPa}$ was considered. The lowest height level 


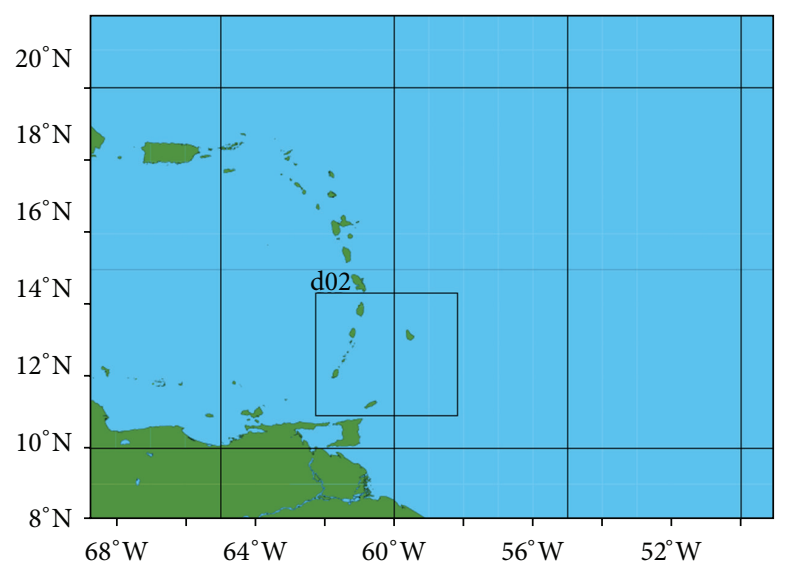

(a)

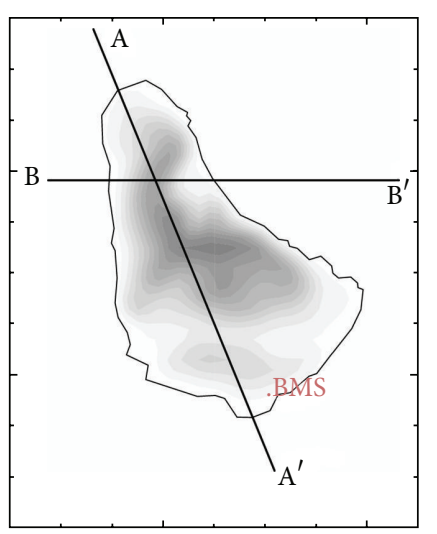

(b)

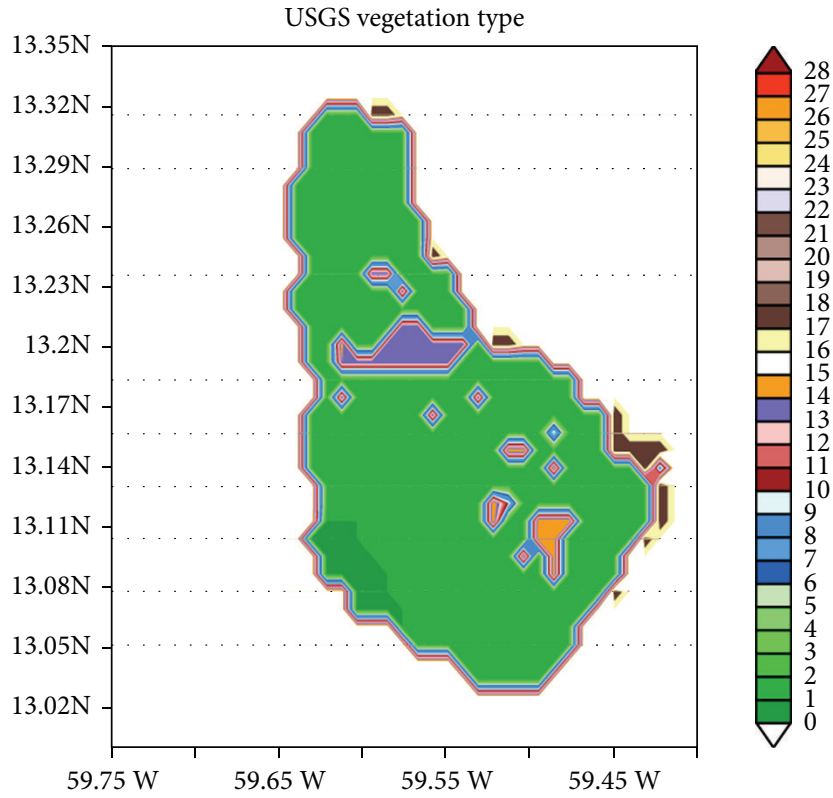

(c)

Figure 3: (a) WRF domains used in the simulations. The label BMS indicates the location of the Barbados Meteorological Office, (b) the WRF representation of the topography of Barbados (in $\mathrm{m}$ ), and (c) the WRF representation of the vegetation type for Barbados. $\mathrm{AA}^{\prime}$ and $\mathrm{BB}^{\prime}$ denote the cross-sections for the following figures.

considered in the model was approximately $30 \mathrm{~m}$ ASL. The initial and the time-dependent lateral boundary conditions were both derived from the Global Forecasting System (GFS) from the National Center for Environmental Prediction (NCEP). An $18 \mathrm{hr}$. simulation was conducted starting at 0600 UTC (0200 LST) 26 August 2008, which allowed for daytime heating within the model.

The Lin et al's microphysics scheme and the Noah Landsurface model were used and the RRTM atmospheric radiation schemes to account for longwave and shortwave radiative interactions. The Mellor-Yamada-Janjic (MYJ) planetary boundary layer scheme was used on both domains. No cumulus parameterization scheme was used for the second domain; however, the first domain used the Betts-Mellor-Janjic (BMJ) scheme.

Three (3) numerical experiments were conducted-a control experiment (CTRL) involving no alterations to the input data and two sensitivity experiments. The first sensitivity experiment (NOTER) reduced the island's topography to $0 \mathrm{~m}$ above sea level. The NOTER experiment would determine the significance, if any, of the forced uplift of the topography on the deep localized convection formation and the contribution of the thermal surface properties. The second sensitivity experiment (SEA) represented the island's surface as water and was designed to determine the thermal properties (i.e., surface heat fluxes) dependency of the phenomenon. However, our main discussion of this study will be focused on the CTRL and NOTER experiments.

\section{Simulation Results}

The results presented are from the analysis of the inner $1 \mathrm{~km}$ grid resolution domain as we are interested in the features of the convective activity, which can best be represented at this 


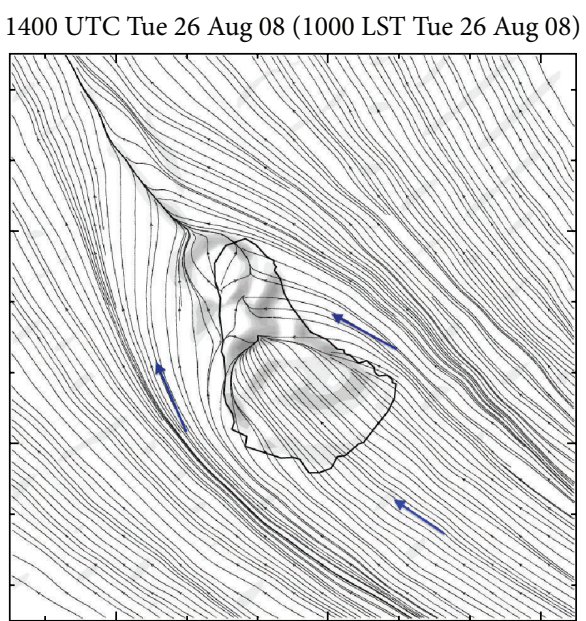

(a)

1400 UTC Tue 26 Aug 08 (1000 LST Tue 26 Aug 08)

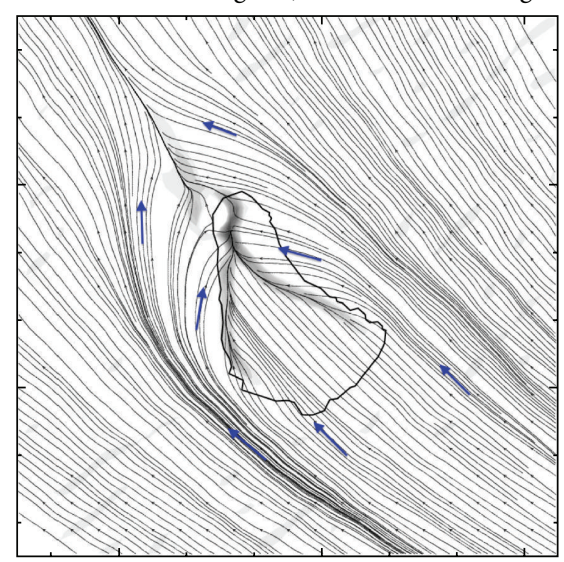

(c)

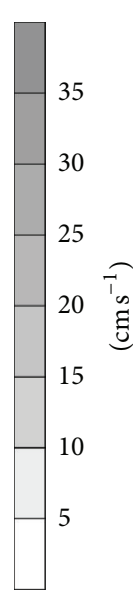

8)

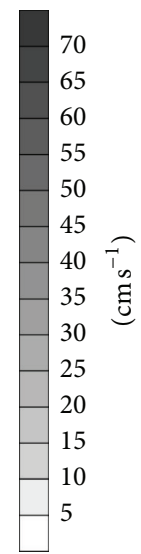

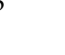

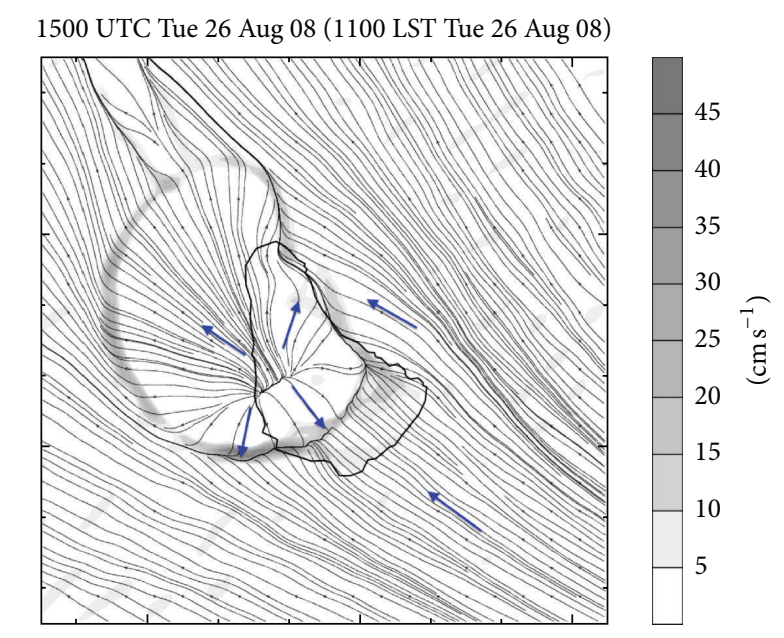

(b)

1500 UTC Tue 26 Aug 08 (1100 LST Tue 26 Aug 08)

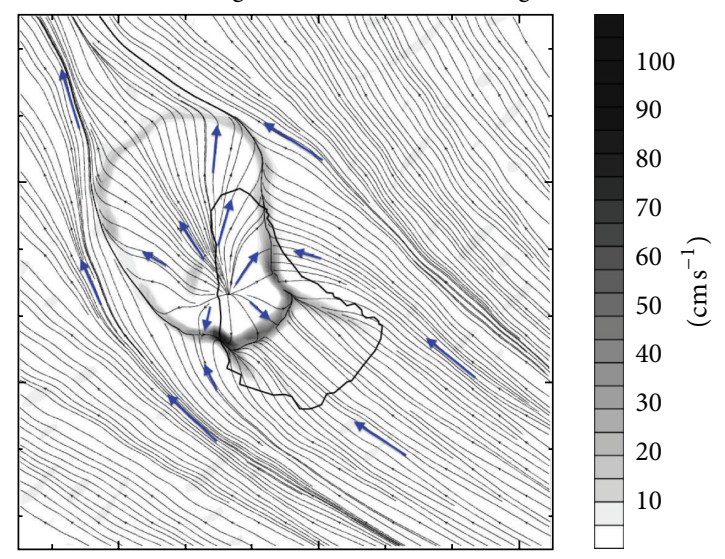

(d)

FIgURE 4: Streamline at $10 \mathrm{~m}$ and vertical velocity at $900 \mathrm{hPa}$ (shaded) for the CTRL experiment at (a) 1400 UTC and (b) 1500 UTC. (c) and (d) are at the same time as (a) and (b) but for the NOTER experiment. The blue arrows indicate the general direction of the streamlines.

TABLE 1: The Barbados meteorological service (BMS) hourly METAR observations for 26 August 2008. BMS is located at $13.04 \mathrm{~N}$, $59.30 \mathrm{~W}$.

\begin{tabular}{lccc}
\hline Time (UTC) & $\begin{array}{c}\text { Wind } \\
\text { direction }\end{array}$ & $\begin{array}{c}\text { Wind speed } \\
\left(\mathrm{ms}^{-1}\right)\end{array}$ & Temperature $\left({ }^{\circ} \mathrm{C}\right)$ \\
\hline 1200 & Variable & 1.5 & 28 \\
1300 & 140 & 3.6 & 29 \\
1400 & 130 & 4.1 & 30 \\
1500 & 140 & 4.1 & 30 \\
1600 & 130 & 3.6 & 30 \\
1700 & 140 & 3.1 & 30 \\
1800 & 150 & 3.6 & 30 \\
1900 & 130 & 2.1 & 29 \\
2000 & 150 & 2.6 & 30 \\
2100 & Variable & 2.1 & 29 \\
\hline
\end{tabular}

resolution. We are further interested in presenting the mesoscale and microscale features from the simulations; however, we should note that the outer domain did capture the synoptic environment accurately.

3.1. The CTRL Simulation. The streamline analysis and vertical motion at $900 \mathrm{mb}$ (Figure 4) indicate the wind flow at 1300 UTC is predominately southeasterly (the zonal wind at $10 \mathrm{~m} \sim-2 \mathrm{~ms}^{-1}$ ) and upward motion near the northern part of the island is initiated. This upward motion is associated with a single convective cell that is generated from the heat source, weakening as it moves southwestward. At 1400 UTC, there is a strong upward motion centered towards the north central part of the island. At 1430 UTC, $10 \mathrm{~m}$ zonal wind is $\sim 2.5 \mathrm{~ms}^{-1}$ and the upward motion is centered along the "base" foothill of the topographic area in the south central.

The simulated radar reflectivity (Figures 5(a) and 5(b)) shows two distinct areas of convection over the northwest and central west regions of the island by 1430 UTC. The smaller lower reflectivity region illustrates a single cellular convective structure and is correlated with the area of positive vertical motion from earlier around 1300 UTC (not shown). 


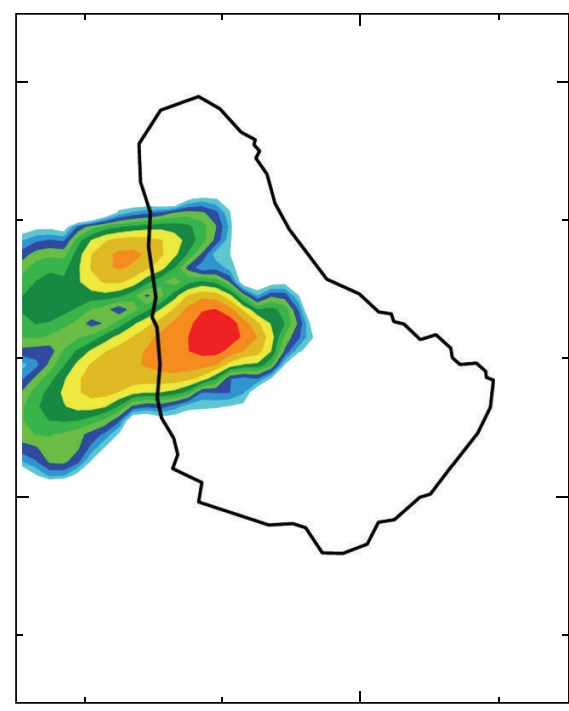

(a)

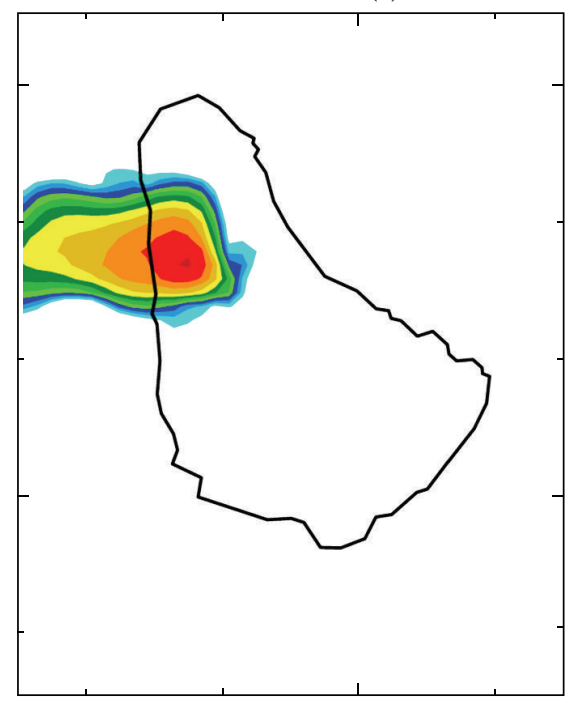

(c)
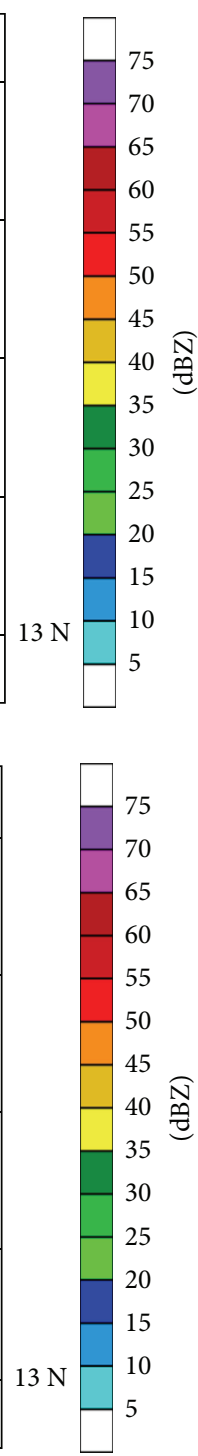

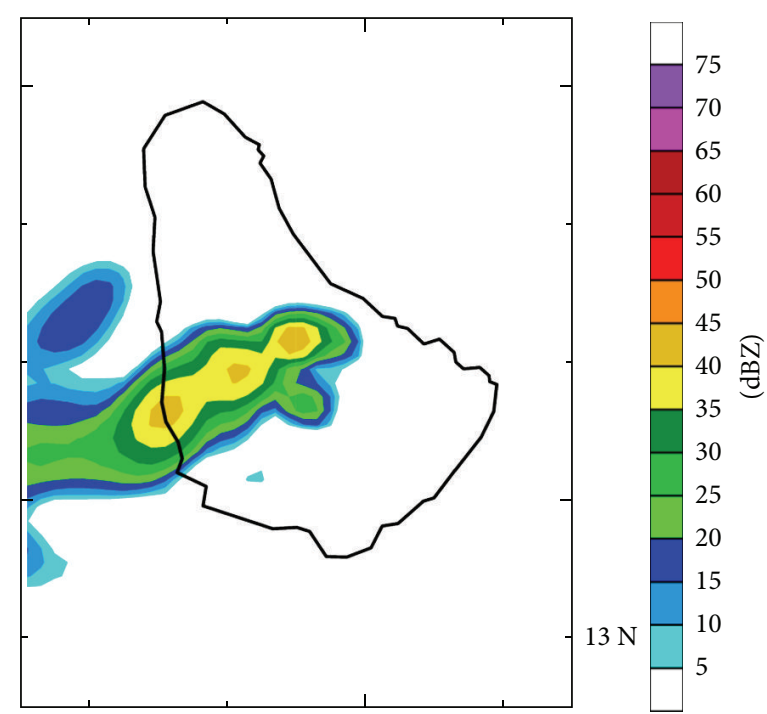

(b)

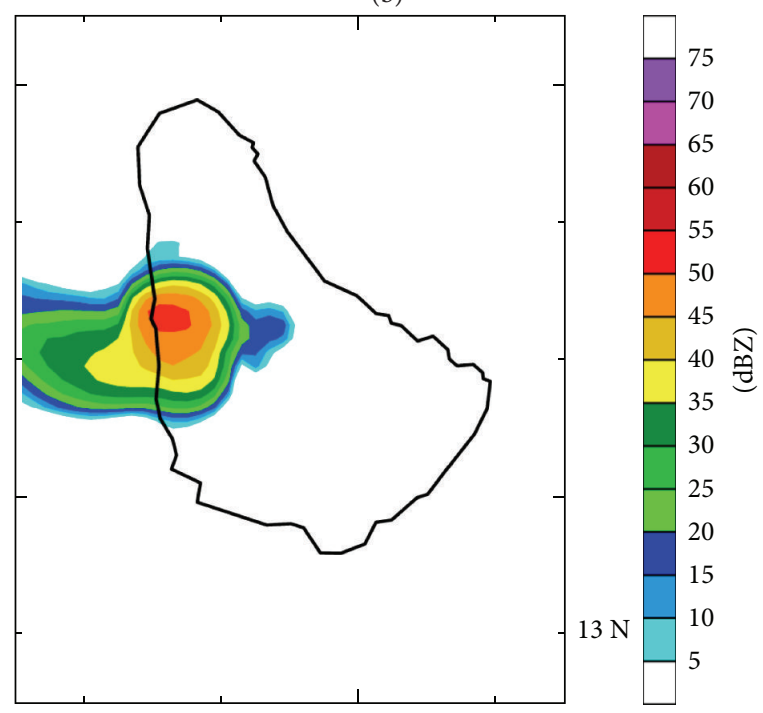

(d)

FIGURE 5: Simulated radar reflectivity for the CTRL experiment valid at (a) 1430 UTC and (b) 1500 UTC; (c) and (d) are at the same time as (a) and (b) but for NOTER.

The larger area in the central west region of the island indicates a multicellular convective structure. It propagates in a southwesterly direction and is distinctly multi-cellular by 1500 UTC. This structure and location are in agreement with the area of cloudiness as indicated by the satellite images (Figure 2).

The $2 \mathrm{~m}$ surface temperature analysis (not shown) indicates surface heating throughout the domain. By 1300 UTC, the isotherm follows the topography, with the minimum temperature $(301.2 \mathrm{~K})$ located over the highest topography. The temperature gradient increases from $2.1 \mathrm{~K}$ difference at $1300 \mathrm{UTC}$ to $8.0 \mathrm{~K}$ at $1430 \mathrm{UTC}$. The isotherm pattern also varies such that the minimum temperature is on the leeward side of the highest elevation (recall the wind is southeasterly).

The north-south cross-section analysis $\left(\mathrm{AA}^{\prime}\right)$ of zonal winds and potential vorticity (Figures 6(a) and 6(b)) indicate the vorticity grows ahead of the topography between
1400 UTC and 1500 UTC. This column of PV grows to 800 $\mathrm{hPa}$ and slightly tilts northwest with height. There is also a weaker area of potential vorticity behind the topography during the same time period. That column grows to $\sim 900 \mathrm{hPa}$ and is not titled.

3.2. NOTER Simulation. The streamline analysis and vertical motion analysis indicate a convective cell being generated in the north-central part of the island and spreads towards the southwest. The wind flow is predominately southeasterly with the $10-\mathrm{m}$ zonal wind $\sim-2.5 \mathrm{~ms}^{-1}$ throughout the simulated period.

The simulated radar reflectivity from the NOTER simulation (Figures 5(c) and 5(d)) indicates a single-cell convective cell over the north-central part of the island. This is associated solely with the land surface thermal properties and sea-breeze formations. The $2 \mathrm{~m}$ surface temperature analysis indicates 


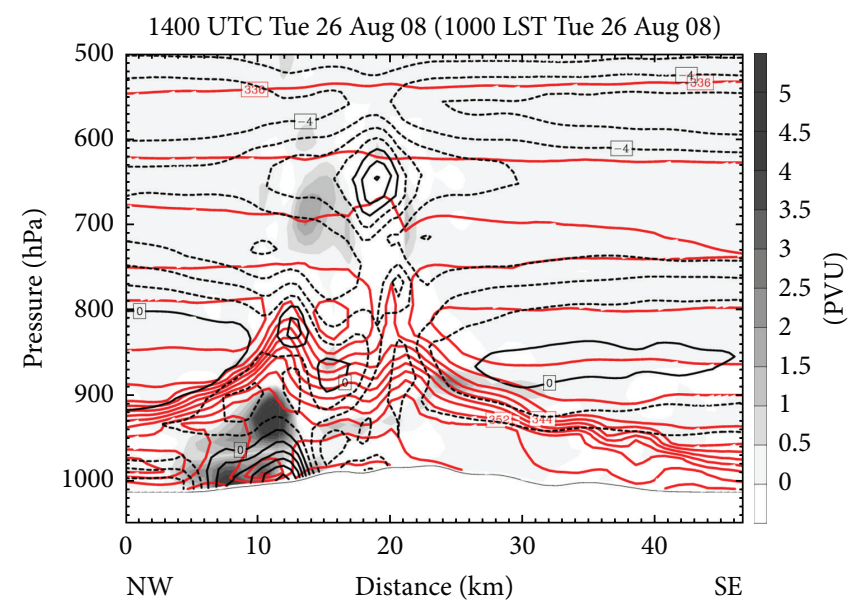

(a)

1400 UTC Tue 26 Aug 08 (1000 LST Tue 26 Aug 08)

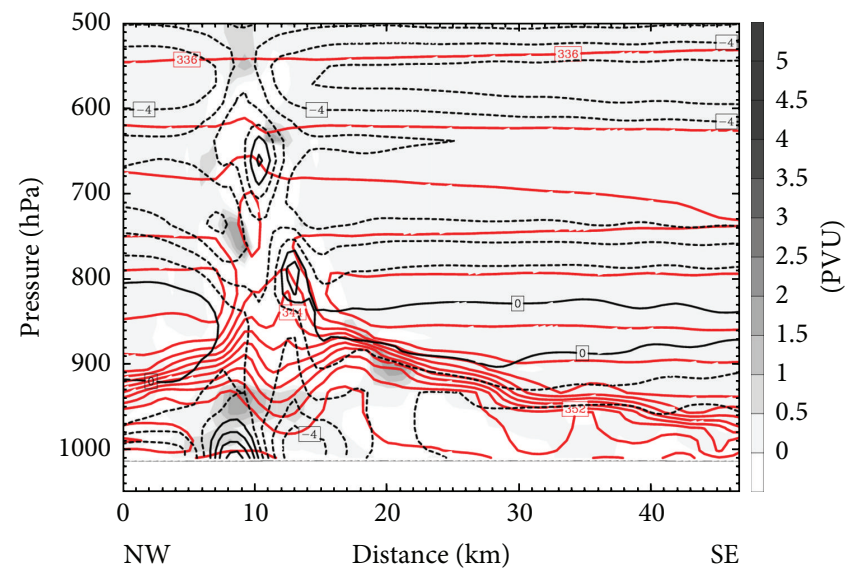

(c)
1430 UTC Tue 26 Aug 08 (1030 LST Tue 26 Aug 08)

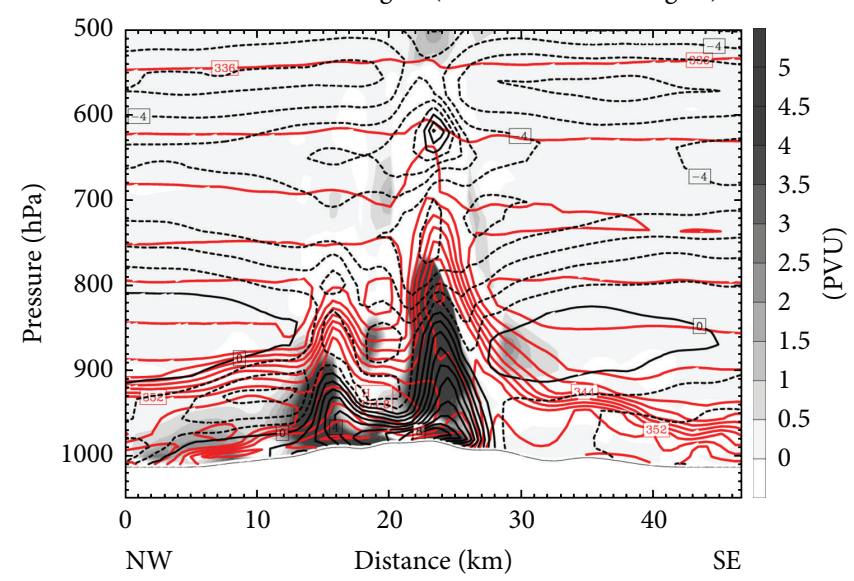

(b)

1430 UTC Tue 26 Aug 08 (1030 LST Tue 26 Aug 08)

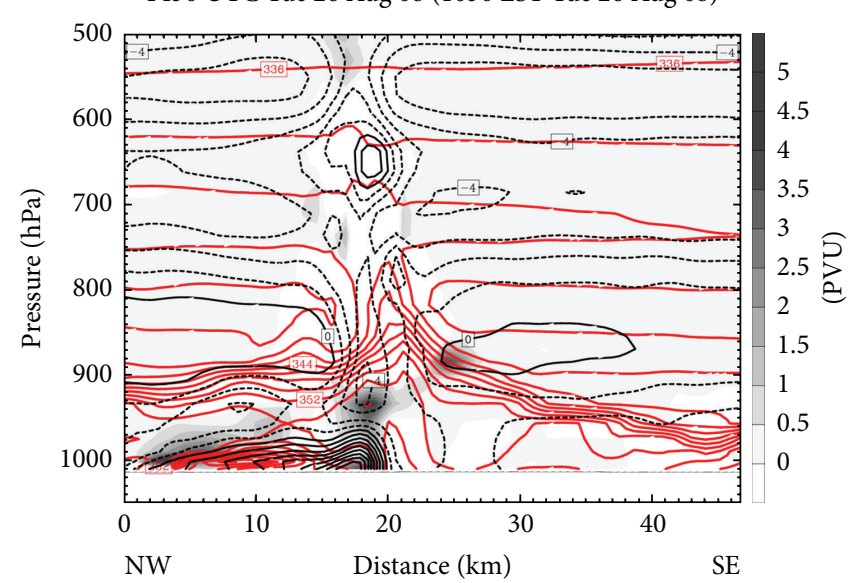

(d)

FIGURE 6: Vertical cross-section ( $\mathrm{AA}^{\prime}$ ) of zonal wind (black contours), equivalent potential temperature (red contours) and potential vorticity (shaded) valid at (a) 1400 UTC, and (b) 1430 UTC for the CTRL experiment; (c) and (d) are for the NOTER experiment.

surface heating at 1300 UTC the isotherm difference across the island is $2.0 \mathrm{~K}$. By $1430 \mathrm{UTC}$, the temperature difference is $6.0 \mathrm{~K}$. The distribution of the isotherms indicates the coolest temperatures are along the coastline, and the temperature increases inwards. The temperatures in the interior of northern part of the island (the narrower part of the island) are warmest. The southern part of the island where there is urban landuse (Figure 3(b)) also indicates warm temperatures. By 1400 UTC the urban area along the south west coast is comparatively warm, and the minimum temperature forms between these two maxima.

The north-south cross-section analysis $\left(\mathrm{AA}^{\prime}\right)$ of zonal winds and potential vorticity (Figures 6(c) and 6(d)) indicate the potential vorticity is generated at 1400 UTC in the lower part of the atmosphere and grows laterally towards the northwest, more so than vertically. This area correlated with changing landuse (Figure 3(c)). The rainfall accumulations for the period simulated most of the rainfall over the west central part of the island (Figure 7). This result is favorable both regarding position and rainfall accumulations observed within the rain-gauge network (Table 2).

\section{Discussions}

The upward motion initiated around 1300 UTC over the north of the island is related to the land surface properties and thermal environment. This conclusion can be determined as the area is similar in intensity and position in both the CTRL and NOTER simulations. Additionally, it is not present in the SEA simulation (not shown). This single convective type cell is associated with the sea-breeze phenomenon as indicated by the vertical winds and the zonal winds in either simulation (Figure 8 ). The $2 \mathrm{~m}$ surface temperatures in that region are larger in the NOTER simulation than the CTRL simulation. This area, north of island, is the thinnest width and furthest distance from the coast given the southwesterly flow; hence, the sea-breeze formation initiates first at this location. The depth of the circulation is larger in the CTRL simulation as a result of the topography, but the location and intensity are similar. The simulations indicate then that an early sea-breeze circulation occurs in the north of the island and moves away; then, second circulation forms more central of the island (in CTRL and NOTER) and dominates. Both of these features are 
TABLE 2: Accumulations from stations within the rain-gauge network in Barbados.

\begin{tabular}{lccc}
\hline Station & ID & Latitude, longitude & Total (mm) \\
\hline BMS, Christ Church & A & $13.04 \mathrm{~N} 59.30 \mathrm{~W}$ & 0.0 \\
Searles, Christ Church & B & $13.05 \mathrm{~N} 59.31 \mathrm{~W}$ & 0.8 \\
Union, St. Philip & $\mathrm{C}$ & $13.07 \mathrm{~N} 59.27 \mathrm{~W}$ & 0.0 \\
Edgecombe, St. Philip & $\mathrm{D}$ & $13.07 \mathrm{~N} 59.31 \mathrm{~W}$ & 12.7 \\
Bowmanston, St. John & $\mathrm{E}$ & $13.10 \mathrm{~N} 59.31 \mathrm{~W}$ & 11.3 \\
Constant, St. George & $\mathrm{F}$ & $13.07 \mathrm{~N} 59.34 \mathrm{~W}$ & 17.8 \\
Husbands, St. James & $\mathrm{G}$ & $13.09 \mathrm{~N} 59.37 \mathrm{~W}$ & 29.6 \\
Joe's river, St. Joseph & $\mathrm{H}$ & $13.13 \mathrm{~N} 59.32 \mathrm{~W}$ & 13.12 \\
Mount All, St. Andrew & $\mathrm{I}$ & $13.13 \mathrm{~N} 59.35 \mathrm{~W}$ & 0.0 \\
Greenland, St. Andrew & $\mathrm{J}$ & $13.15 \mathrm{~N} 59.34 \mathrm{~W}$ & 17.6 \\
Sion Hill, St. James & $\mathrm{K}$ & $13.14 \mathrm{~N} 59.37 \mathrm{~W}$ & 41.1 \\
Warleigh, St. Peter & L & $13.14 \mathrm{~N} \mathrm{59.38W}$ & 63.5 \\
\hline
\end{tabular}

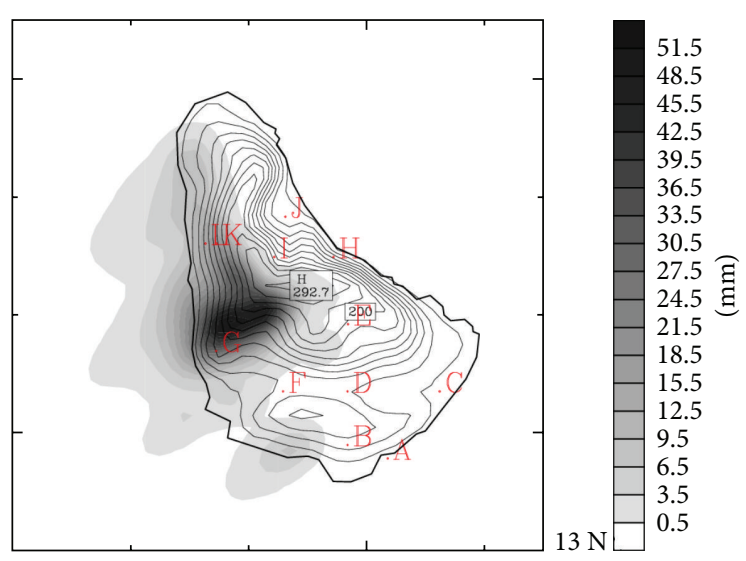

FIGURE 7: Rainfall accumulations for the $12 \mathrm{hr}$ period forecasted from 1200 UTC 26 Aug 2008. Letter symbols denote the stations listed in Table 2.

in agreement with Savijärvi and Matthews [10], except for the timing of the event.

The temperature difference on the island between 1300 UTC and 1500 UTC indicates that the difference is consistently smaller for the NOTER run than the CTRL. The distribution also varies. These findings highlight the importance of the topography to creating a blocking scenario such that the surface temperatures can increase significantly in some places, thus, transforming the event to a steady heat island type perturbation. Additionally, because of the elevated surface, the instabilities are generated higher in the atmosphere (around $950 \mathrm{mb}$ level). Smith et al. [4] deduced that the trade-wind speed determines the location of the strongest uplift of airmass and, thus, cloud formation over Dominica $\left(15^{\circ} \mathrm{N}, 61^{\circ} \mathrm{W}\right)$ - a volcanic island in the trade-wind zone of the Caribbean with highest topography $\sim 1.4 \mathrm{~km}$. For weak trade winds (zonal wind $<5 \mathrm{~ms}^{-1}$ ), clouds form over the pinnacle or on the leeward side and the formation is related to the thermal convection. The findings of this case study in Barbados indicate a similar process.
The potential vorticity grows ahead of the topography in CTRL (see Figure 6). That location in NOTER indicates no PV; however, the locations of PV in NOTER are seen in the CTRL runs, though the magnitude is stronger. This finding indicates that the PV generated from diabatic heating in NOTER is not sufficient for the cloudiness observed, but the frictional component of the PV observed in the CTRL run is a necessary component.

\section{Conclusions}

The WRF simulations are conducted for the rapid convective initiate and flash-flooding event of 26 August 2008 over Barbados. The modeling results indicate that the mechanisms for the development of deep convective clouds include the low-level moisture convergence as a result of the temperature differential between the land and the ocean, that is, the seabreeze phenomenon and forced uplift from the topography. These two factors lead to the destabilizing of the lowest atmospheric levels. In the case of the localized convection in Barbados, it has been found that the following ingredients lead to the deep convection formation in this case.

(1) The clear morning skies in the boreal summertime permit maximum exposure of the land to the incoming solar radiation and thus encourage buoyancy and reduce very quickly static stability in the lower level of the boundary layer, that is, encourage boundary layer mixing.

(2) The northern part of the island is generally more prone to low-level convergence. In times when the surface heating is intense, this convergence can be significant in initiating convection.

(3) The $2 \mathrm{~ms}^{-1}$ southeasterly wind allowed for maximum time (distance) over the land for heat and moisture flux exchanges in the layer of atmosphere in contact with the surface.

(4) The topography created a blocking scenario, allowing for the maintenance of warm surface temperatures and a small heat island effect. 


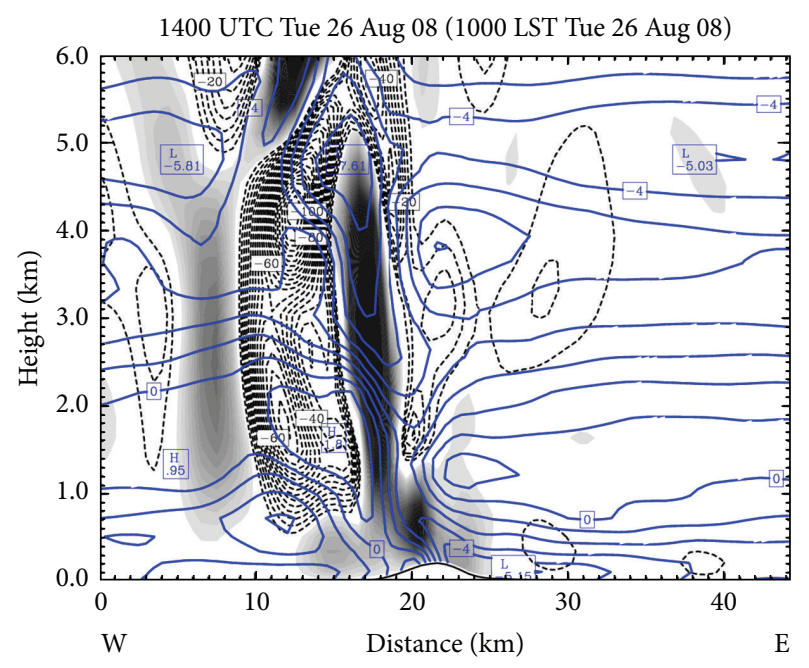

(a)

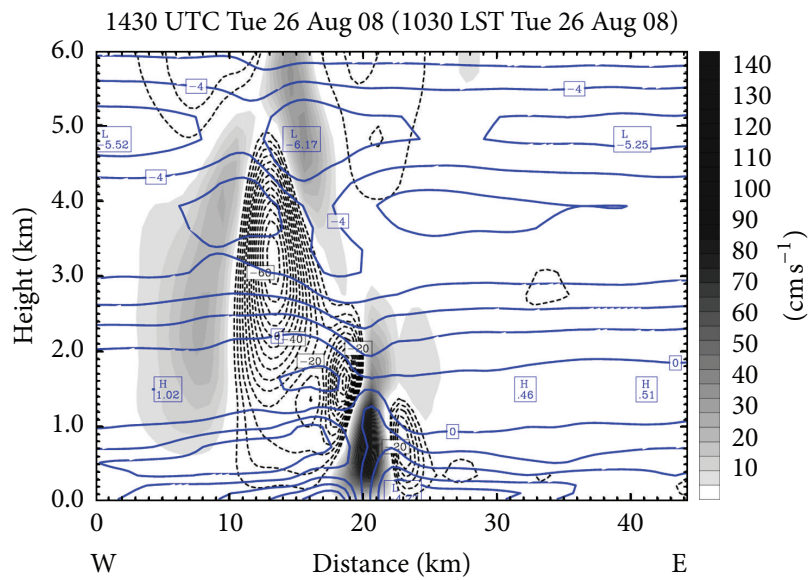

(c)

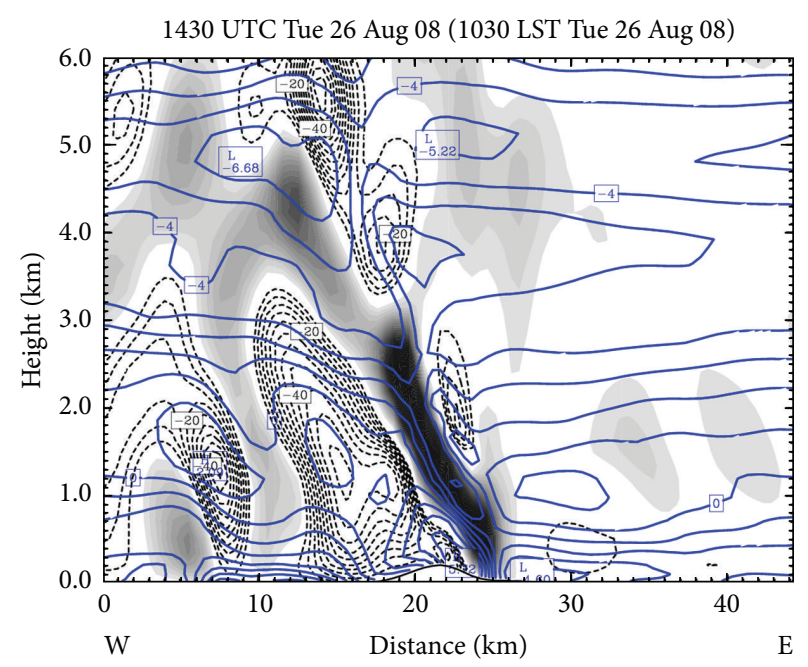

(b)

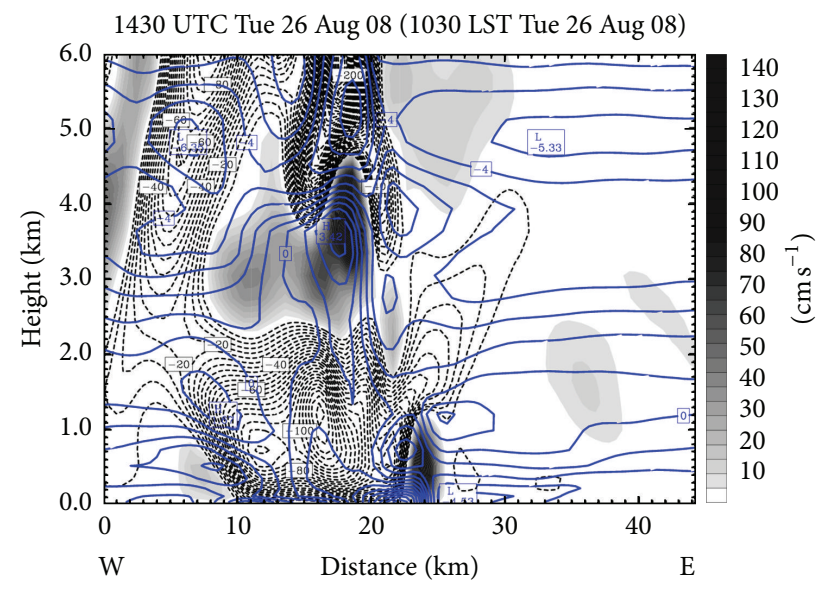

(d)

FIgURE 8: Cross-section $\mathrm{BB}^{\prime}$ for vertical velocity (shaded) and zonal winds for the CTRL experiment valid at (a) 1400 UTC and (b) 1430 UTC; (c) and (d) are the same but for the NOTER experiment.

(5) The shallow topography does cause some upward forcing of air. Thus, in a sufficiently statically unstable environment this slight uplift can provide sufficiency upward motion for an air parcel to grow into a cloud.

The WRF model appears to be capable of properly producing the low-level flow over the island, as well as the orientation of the divergence and convergence patterns throughout the depth of the atmosphere. These results are heartening to use the WRF as a resource for deep convection in the region for possible water resource managers and disaster managers. Nevertheless, from these modeling experiments, one can be easily satisfied that the localized convection being studied was not a part of the forcing meteorological data. Further examinations of similar cases are encouraged not only to concretize the findings, but also to provide threshold values on other variables (such as low-level moisture) for forecasters. In addition to considering more cases, MODIS land surface temperature datasets can also be analyzed to determine the thermal footprint of the island.

\section{Acknowledgments}

The authors acknowledge the Cooperative Institute for Research in the Atmosphere, Colorado State University, for supplying the GOES-8 visible images and the Caribbean Institute for Meteorology and Hydrology, Barbados, for providing the rainfall data. Thanks are also given to Dr. Gregory Jenkins at Howard University for suggestions. This research was supported by Grant W911NF-09-1-0441 from the US Army Research Office and NSF AGS-1209296.

\section{References}

[1] A. Giannini, Y. Kushnir, and M. A. Cane, "Interannual variability of Caribbean rainfall, ENSO, and the Atlantic Ocean," Journal of Climate, vol. 13, no. 2, pp. 297-311, 2000.

[2] D. E. Kingmill, "Convection initiation associated with a seabreeze front, a gust front, and their collision," Monthly Weather Review, vol. 123, no. 10, pp. 2913-2933, 1995.

[3] D. J. Kirshbaum and R. B. Smith, "Orographic precipitation in the tropics: large-Eddy simulations and theory," Journal of the Atmospheric Sciences, vol. 66, no. 9, pp. 2559-2578, 2009. 
[4] R. B. Smith, J. R. Minder, A. D. Nugent et al., "Orographic precipitation in the tropics: the dominica experiment," Bulletin of the American Mathematical Society, vol. 93, no. 10, pp. 15671579, 2012.

[5] C. C. Skeete, An Historical Description of the Weather of the Island of Barbados, West Indies, During the Period 1901 to 1960, Barbados Government Printing, Bridgetown, Barbados, 1964.

[6] N. A. Crook and D. F. Tucker, "Flow over heated terrain-part I: linear theory and idealized numerical simulations," Monthly Weather Review, vol. 133, no. 9, pp. 2552-2564, 2005.

[7] M. R. Jury, S. Chiao, and E. W. Harmsen, "Mesoscale structure of trade wind convection over Puerto Rico: composite observations and numerical simulation," Boundary-Layer Meteorology, vol. 132, no. 2, pp. 289-313, 2009.

[8] M. Garstang, P. D. Tyson, and G. D. Emmitt, "The structure of Heat Islands," Reviews of Geophysics, vol. 13, no. 1, pp. 139-165, 1975.

[9] Y. Mahrer and R. A. Pielke, "Numerical simulation of the airflow over Barbados," Monthly Weather Review, vol. 104, no. 11, pp. 1392-1402, 1976.

[10] H. Savijärvi and S. Matthews, "Flow over Small Heat Islands: a numerical sensitivity study," Journal of the Atmospheric Sciences, vol. 61, no. 7, pp. 859-868, 2004. 

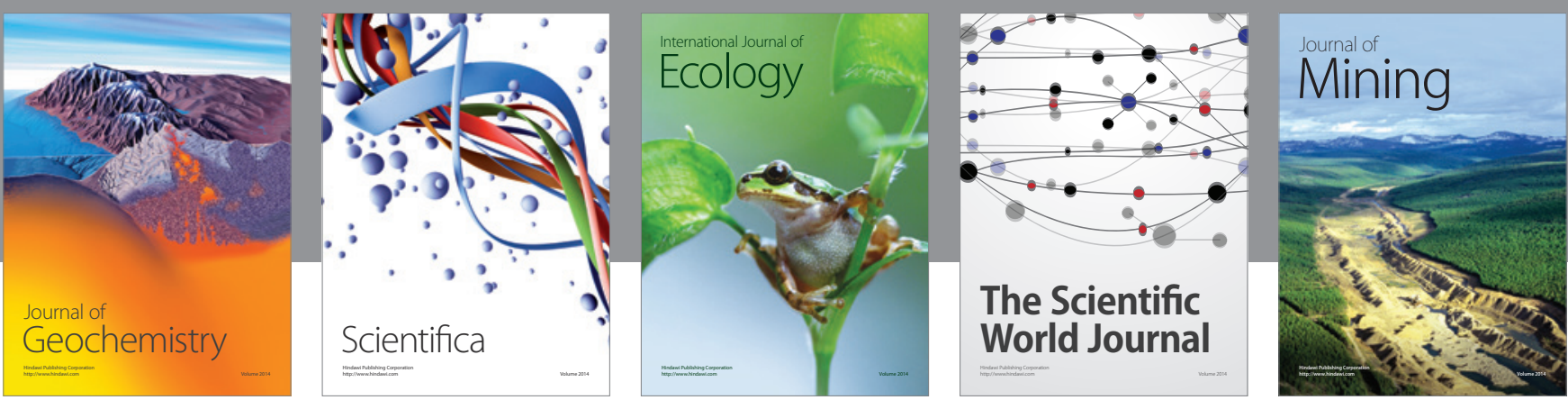

The Scientific World Journal
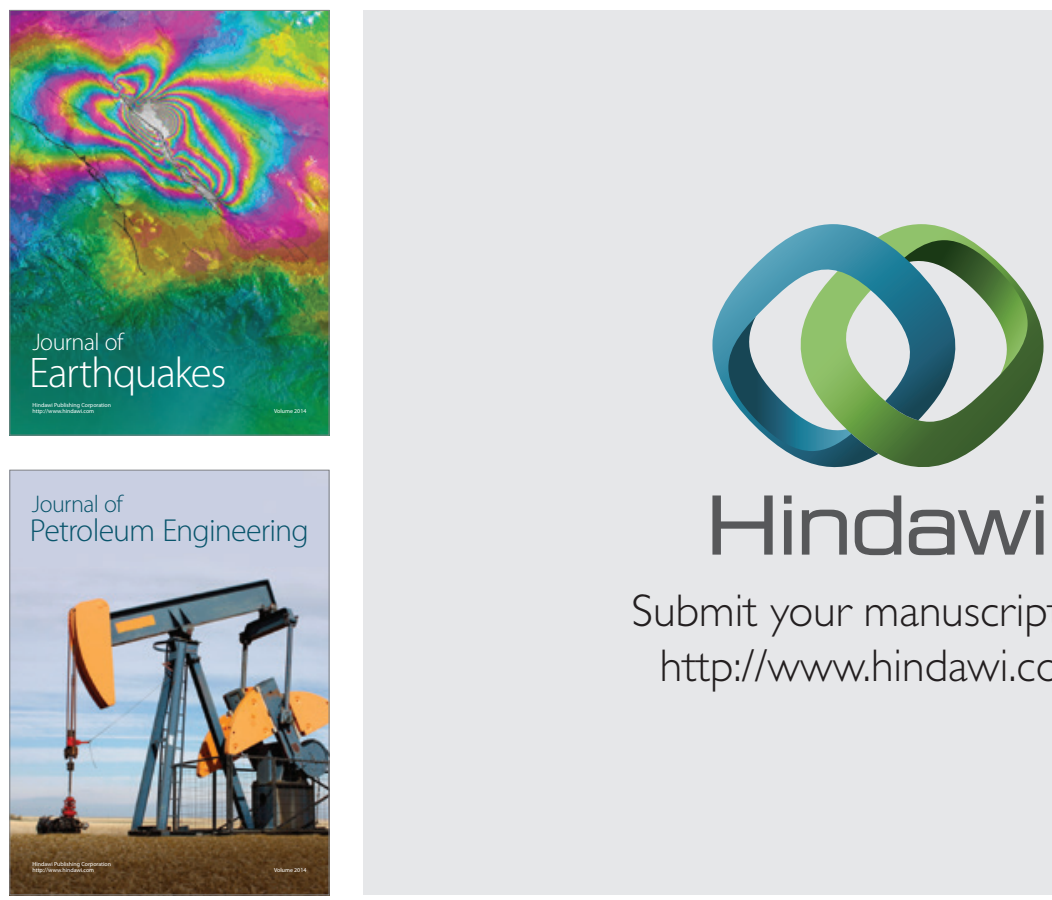

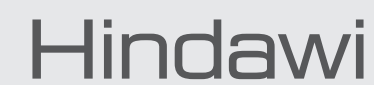

Submit your manuscripts at

http://www.hindawi.com
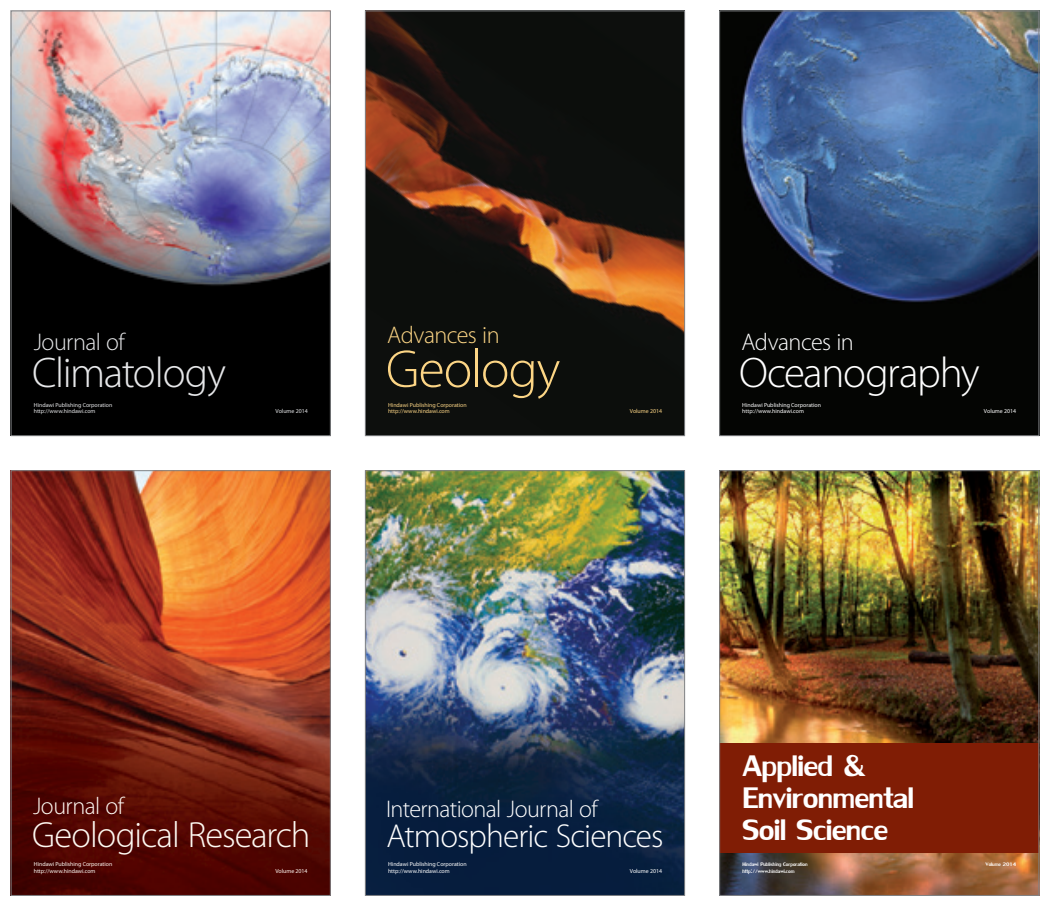
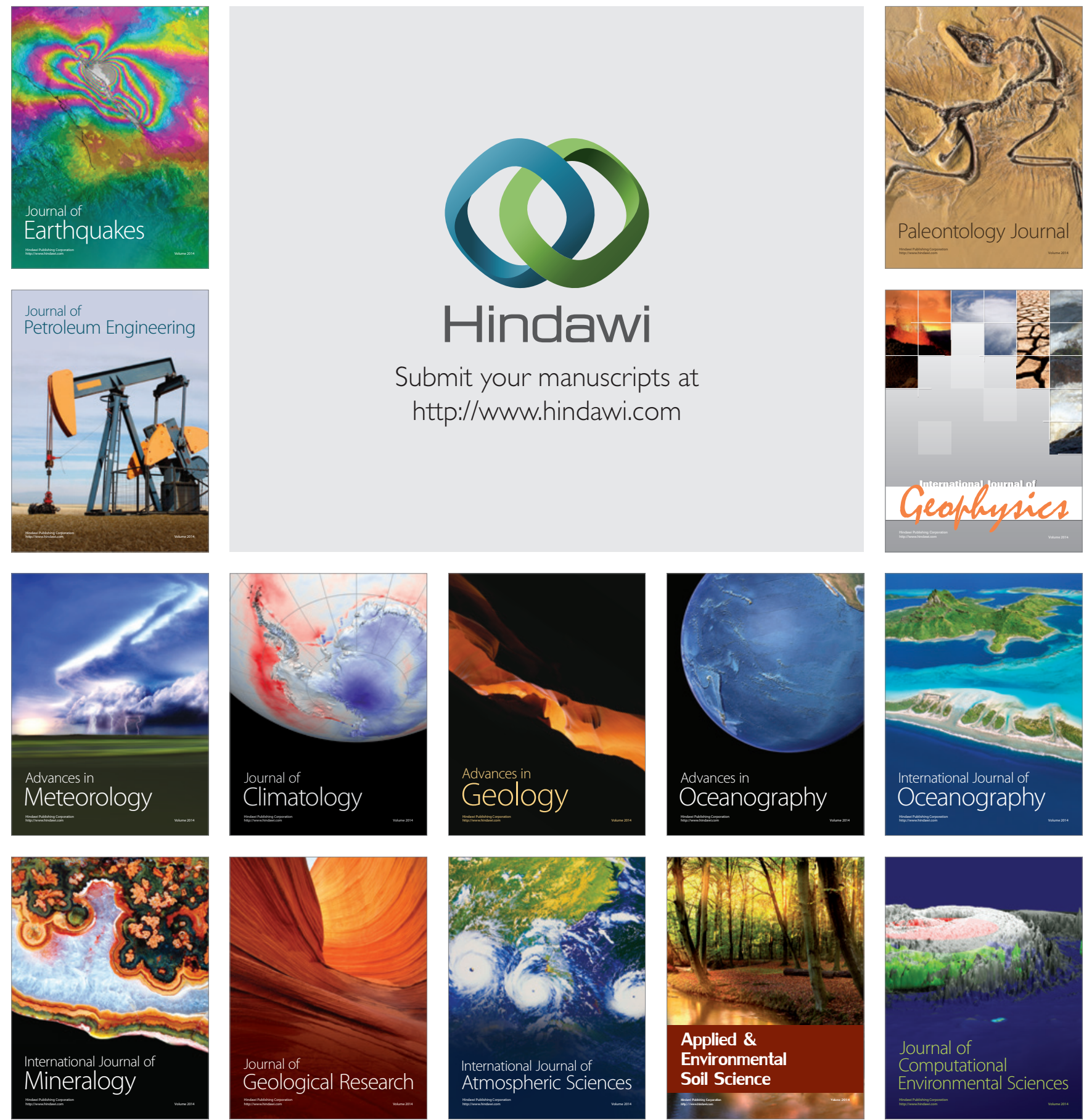